\title{
ANALISA PERAMALAN PENJUALAN PRODUK SUSU KENTAL MANIS CARNATION PADA CV PANGAN MAKMUR IRJA SORONG
}

\author{
Menik Wijayanti, SE,M.Sc \\ Akuntansi Keuangan Publik \\ Program Studi Diploma IV Akuntansi \\ Politeknik Katolik Saint Paul Sorong \\ Email: menikwijayanti29@yahoo.co.id
}

\begin{abstract}
ABSTRAK
Tujuan dari penelitian ini adalah membandingkan anggaran penjualan yang di buat perusahaan dengan anggaran penjualan berdasarkan metode jumlah kuadrat terkecil. Hasil penelitian menunjukkan adanya kenaikan jumlah penjualan produk susu kental manis carnation lebih meningkat sebesar 56.756 karton dari perhitungan penjualan yang di buat oleh manajemen perusahaan yaitu sebesar 55.611 karton. Berdasarkan hasil analisis korelasi menunjukkan adanya pengaruh yang sangat kuat dari penjualan produk susu kental manis carnation dengan menggunakan metode kuadrat terkecil karena nilai korelasi $(\mathrm{R})=0,915$ atau $92 \%$ dengan pernyataan koefisien korelasi jika nilai korelasi $>0,70$ maka hubungan korelasi tersebut sangat kuat. Manajemen perusahaan perlu menggunakan metode kuadrat terkecil dalam membuat ramalan penjualan karena metode ini sangat teliti mendeskripsikan angka-angka dalam perhitungan dan dapat mencegah adanya kesalahan dalam pengisian data, membuat data semakin akurat serta dapat mempersingkat waktu untuk menghitung trend penjualan yang sudah ditentukan.
\end{abstract}

Kata kunci : Peramalan penjualan, Metode jumlah kuadrat terkecil.

\section{PENDAhuluan}

\subsection{Latar Belakang Masalah}

Anggaran merupakan rencana manajemen untuk keperluan perencanaan dan pengendalian, dengan asumsi bahwa langkah-langkah positif akan diambil oleh pelaksana anggaran untuk merealisasikan rencana yang telah disusun.

Anggaran penjualan merupakan langkah awal dalam menyiapkan anggaran induk karena volume penjualan yang

diestimasi mempengaruhi hampir semua item-item lainnya dalam anggaran induk (J.K. Shim \& J.G. Siegel, 2000: 56). Anggaran penjualan merupakan dasar penyusunan anggaran lainnya dan pada umumnya anggaran penjualan disusun terlebih dahulu sebelum menyusun anggaran lainnya. Karena itu anggaran penjualan disebut anggaran kunci (M. Nafarin, 2004:23).

Tujuan utama pendirian perusahaan pada umumnya adalah untuk mendapatkan laba yang maximal dengan pengeluaran biaya yang minimal. Setiap perusahaan, baik itu perusahaan manufaktur maupun perusahaan perdagangan haruslah menjaga persediaan yang cukup agar kegiatan operasi perusahaannya dapat berjalan dengan lancar. Hal yang perlu diperhatikan adalah bahan baku yang dibutuhkan hendaknya cukup tersedia sehingga dapat menjamin kelancaran produksi. Penting bagi setiap jenis perusahaanuntuk mengadakan perencanaan atas persediaan, karena dapat membantu efisiensi penggunaan dalam persediaan.

Persediaan bila ditentukan terlalu besar akan menghadapi berbagai resiko seperti besarnya beban bunga yang harus ditanggung, memperbesar biaya penyimpanan dan pemeliharaan di gudang, memperbesar kemungkinan kerugian karena kerusakan dan turunnya kualitas bahan, sehingga semua ini akan memperkecil keuntungan yang akan didapat perusahaan. Demikian pula sebaliknya, bila persediaan terlalu kecil akan mempunyai efek yang menekan keuntungan, karena kemungkinan kekurangan bahan baku mengakibatkan perusahaan tidak bisa bekerja dengan luas produksi yang optimal (Sutrisno, 2003:96). Pengantisipasian permasalahan tersebut dilakukan prediksi 
terhadap kemungkinan-kemungkinan terjadinya penurunan atau kenaikan penjualan pada periode yang akan datang dengan diperolehnya informasi yang akurat sehingga perusahaan dapat mempersiapkan strategi-strategi yang akan ditempuh menghadapi kondisi tersebut (Rangkuti, 2007:1)

Peramalan tidak hanya dilakukan untuk menentukan jumlah produk yang akan diproduksi dan dijual tetapi bermanfaat pula untuk perencanaan persediaan barang jadi. Ketersediaan barang jadi menjadi penting, sebagai salah satu alat untuk mengantisipasi keadaan pasar sehingga produk senantiasa tersedia dan dapat memenuhi permintaan konsumen.

CV. Pangan Makmur IRJA, sebagai salah satu distributor Nestle yang berkedudukan di kota sorong yang berfokus memasarkan produk Nestle terus melakukan ekspansi untuk memperluas daerah pemasarannya. Dalam menentukan target penjualannya perusahaan menggunakan metode kualitatif, yaitu berdasarkan survey dan pendapat dari staf yang berkaitan langsung dengan kegiatan penjualan. Saat ini CV Pangan Makmur IRJA telah memiliki empat daerah pemasaran yaitu wilayah Kota Sorong, Kabupaten Sorong, Kabupaten Sorong Selatan dan Kabupaten Raja Ampat.

Berdasarkan hal tersebut di atas maka penulis tertarik mengadakan penelitian di CV. Pangan Makmur IRJA terkait dengan ramalan penjualan Susu kental manis Carnation, dengan judul : “ ANALISA PERAMALAN PENJUALAN PRODUK SUSU KENTAL MANIS CARNATION TAHUN 2015".

\subsection{Batasan Masalah}

Dalam penelitian ini penulis hanya memberikan batasan masalah pada penjualan produk susu kental manis Carnation sebagai produk terlaris di pasaran dari CV. Pangan Makmur IRJA dari tahun 2010 - 2014 untuk meramal penjualan tahun 2015.

Berdasarkan latar belakang masalah yang telah penulis uraikan di atas, maka yang menjadi pokok permasalahan dalam penulisan penelitian ini adalah "Bagaimana ramalan penjualan produk Susu Kental Manis Carnation pada CV. Pangan Makmur IRJA Sorong?"

\subsection{Rumusan Masalah}

Masalah adalah suatu penyimpangan dari ketidakseimbangan antara apa yang diinginkan dan yang seharusnya terjadi dengan yang sebenarnya terjadi. Rumusan masalah yang terjadi pada CV. Pangan Makmur IRJA Sorong adalah sebagai berikut:

Penjualan produk Susu Kental Manis Carnation pada CV. Pangan Makmur IRJA belum mencapai target.

\subsection{Tujuan dan Manfaat Penelitian}

\subsubsection{Tujuan Penelitian}

Berdasarkan masalah yang dikemukakan, tujuan yang ingin dicapai dalam penelitian ini adalah :

Membandingkan anggaran penjualan yang di buat perusahaan dengan anggaran penjualan berdasarkan metode jumlah kuadrat terkecil (The LeastSquare's Method).

\subsubsection{Manfaat Penelitian}

Hasil penelitian ini diharapkan dapat memberikan manfaat sebagai berikut:

1. Manfaat Teoritis

a. Memperluas pengetahuan penulis mengenai tren penjualan pada produk susu kental manis Carnation

b. Dapat melakukan perbandingan antara teori yang penulis peroleh dari buku maupun perkuliahan dengan aplikasinya pada CV. Pangan Makmur IRJA Sorong tempat penulis melakukan penelitian.

c. Menjadi referensi untuk penelitian-penelitian berikutnya yang relevan.

2. Manfaat Praktis

Hasil penelitian ini diharapkan mempunyai manfaat praktis bagi:

a. Penulis

Hasil penelitian ini merupakan tambahan pengetahuan mengenai 
penjualan produk susu kental manis Carnation pada CV. Pangan Makmur IRJA Sorong.

b. CV. Pangan Makmur IRJA

Hasil penelitian ini dapat dijadikan pedoman atau referensi untuk meramal (forecast) atau memperkirakan jumlah penjualan produk susu kental manis Carnation di tahun yang akan datang dengan menggunakan metode yang tepat.

c. Masyarakat.

Memberikan pengetahuan dan pemahaman masyarakat dalam memilih dan membeli produk susu kental manis yang berkualitas dengan harga terjangkau serta sesuai dengan kebutuhan.

\section{TINJAUAN PUSTAKA}

\subsection{Pengertian Anggaran}

Anggaran merupakan rencana manajemen untuk keperluan perencanaan dan pengendalian, dengan asumsi bahwa langkah-langkah positif akan diambil oleh pelaksana anggaran untuk merealisasikan rencana yang telah disusun.

Pengertian anggaran seperti yang dikemukakan oleh Horngren dkk. (2000), yaitu: "A budget is a quantitative expression for a set time period of proposed future plan of action by managament".

Dari pengertian di atas, dapat diartikan bahwa anggaran adalah pernyataan kuantitatif untuk jangka waktu tertentu dari rencana tindakan dan suatu alat bantu untuk mengkoordinasikandan mengimplementasikan rencana ini.

Pengertian lain dari anggaran seperti yang dinyatakan oleh M. Munandar (2001), adalah: "Business budget atau budget (anggaran) ialah suatu rencana yang disusun secara sistematis, yang meliputi seluruh kegiatan perusahaan, yang dinyatakan dalam unit (kesatuan) moneter dan berlaku untuk jangka waktu (periode) tertentu yang akan datang".

Dari pengertian tersebut nampaklah bahwa anggaran mempunyai 5 unsur, yaitu:

1. Rencana, ialah suatu penentuan terlebih dahulu tentang aktivitas atau kegiatan yang akan dilakukan di waktu yang akan datang.

2. Anggaran juga merupakan suatu rencana, karena anggaran merupakan penentuan terlebih dahulu tentang kegiatan-kegiatan perusahaan di waktu yang akan datang.

3. Meliputi seluruh kegiatan perusahaan, yaitu mencakup semua kegiatan yang akan dilakukan oleh semua bagianbagian yang ada dalam perusahaan.

4. Dinyatakan dalam unit moneter, yaitu unit (kesatuan) yang dapat diterapkan pada berbagai kegiatan perusahaan yang aneka ragam. Adapun unit moneter yang berlaku di Indonesia ialah unit "rupiah".

5. Jangka waktu tertentu yang akan datang, yang menunjukkan bahwa anggaran berlakunya untuk masa yang akan datang. Ini berarti bahwa apa yang dimuat di dalam anggaran adalah taksiran-taksiran (forecast) tentang apa yang akan terjadi serta apa yang akan dilakukan di waktu yang akan datang.

Ellen Christina dkk (2001) mengemukakan bahwa: "Anggaran merupakan suatu rencana yang disusun secara sistematis dalam bentuk angka dan dinyatakan dalam unit moneter yang meliputi seluruh kegiatan perusahaan jangka waktu (periode) tertentu di masa yang akan datang".

\subsection{Ruang Lingkup Anggaran}

Dari sudut ruang lingkup ataupun intensitas penyusunan anggaran perusahan, ada 2 jenis anggaran perusahaan, yakni:

1. Anggaran perusahaan yang bersifat komprehensif atau disebut comprehensive budget, adalah anggaran perusahaan yang disusun dengan ruang lingkup yang menyeluruh yang mencakup seluruh aktivitas perusahaan, baik di bidang pemasaran, produksi, keuangan, personalia, maupun administrasi.

2. Anggaran perusahaan yang bersifat parsial atau disebut partial budget, adalah anggaran perusahaan yang disusun dengan ruang lingkup yang terbatas yang hanya mencakup sebagian dari kegiatan perusahaan, misal terbatas 
pada kegiatan pemasaran saja, atau produksi saja, atau keuangan saja.

\subsection{Karakteristik Anggaran}

Adapun karakteristik umum anggaran adalah:

1. Dinyatakan dalam satuan keuangan dan satuan selain keuangan.

2. Umumnya mencakup jangka waktu satu tahun.

3. Berisi komitmen atau kesanggupan manajemen yang berarti bahwa para manajer setuju menerima tanggung jawab untuk mencapai sasaran yang ditetapkan dalam anggaran.

4. Usulan anggaran ditelaah dan disetujui oleh pihak yang berwenang lebih tinggi dari penyusun anggaran

5. Sekali disetujui, anggaran hanya dapat diubah di bawah kondisi tertentu.

6. Secara berkala, kinerja keuangan sesungguhnya dibandingkan dengan anggaran dan selisihnya dianalisis dan dijelaskan.

\subsection{Penggolongan dan Fungsi Anggaran}

Suatu anggaran yang baik harus mencakup seluruh kegiatan perusahaan, sehingga fungsi-fungsi anggaran dapat berjalan baik pula. Anggaran yang menyeluruh semacam itu sering dinamakan comprehensive budget.

Adapun komponen (penggolongan) comprehensive budget adalah sebagai berikut:

1. Subtantive Plan, meliputi:

a. Tujuan umum perusahaan

b. Tujuan khusus perusahaan

c. Strategi perusahaan

d. Penentuan asumsi dasar yang akan dipakai seterusnya oleh perusahaan.

2. Financial Plan, terdiri dari:

1) Anggaran Jangka Panjang, meliputi:

a. Penjualan, biaya dan laba.

b. Penentuan besarnya modal

c. Penentuan tambahan modal

d. Perkiraan aliran dana

e. Perkiraan kebutuhan tenaga kerja.

2) Anggaran Tahunan, terdiri dari:

a. Anggaran operasional, meliputi:

1. Anggaran proyeksi laba-rugi
2. Anggaran pembantu laporan laba-rugi, terdiri dari:

a. Anggaran Penjualan

b. Anggaran Produksi

c. Anggaran biaya produksi

d. Anggaran biaya umum dan administrasi

e. Anggaran type appropriasi, meliputi:

1. Anggaran iklan dan promosi

2. Anggaran penelitian

3. Anggaran pemeliharaan dan lain-lain

(b) Anggaran finansial, meliputi:

a. Anggaran neraca

b. Anggaran pembantu neraca, terdiri dari:

1. Anggaran kas

2. Anggaran piutang

3. Anggaran penambahan modal

4. Anggaran penyusutan aktiva tetap

(3) Anggaran Variabel

(4) Data Statistik Pembantu, terdiri:
a. Analisis breakeven atau analisis cost-profit-volume.
b. Biaya standar

(5) Laporan Intern, meliputi:

a. Laporan statistik

b. Laporan khusus.

c. Laporan hasil pelaksanaan.

Dalam kaitannya dengan masalah jangka waktu (periode) anggaran (budget) dikenal dengan dua macam anggaran, yaitu:

1. Anggaran Strategis (Strategic budget), ialah anggaran yang berlaku untuk jangka panjang, yaitu jangka waktu yang melebihi satu periode akuntansi (melebihi satu tahun).

2. Anggaran Taktis (Tactical budget), ialah anggaran yang berlaku untuk jangka pendek, yaitu satu periode akuntansi atau kurang.

Anggaran mempunyai beberapa macam fungsi, antara lain:

1. Fungsi Perencanaan, .

2. Fungsi Koordinasi, .

3. Fungsi Komunikasi,

4. Fungsi Motivasi,.

5. Fungsi Pengawasan dan Evaluasi, .

6. Fungsi Pendidikan, 


\subsection{Langkah-langkah Penyusunan Anggaran}

Langkah-langkah penyusunan anggaran secara luas dapat dikelompokkan ke dalam (5) tahap, yaitu sebagai berikut:

1. Perencanaan.

2. Prakiraan

3. Penyesuaian

4. Implementasi.

5. Penilaian (Evaluasi)

\subsection{Prosedur Penyusunan Anggaran}

Pada garis besarnya tugas mempersiapkan dan menyusun anggaran ini dapat didelegasikan kepada:

1. Bagian Administrasi, bagi perusahaan kecil.

2. Panitia Anggaran, bagi perusahaan besar.

\subsection{Pengertian Anggaran Penjualan}

Pengertian anggaran penjualan menurut M. Munandar (2001), mengemukakan bahwa:

"Anggaran penjualan (sales budget) ialah anggaran yang merencanakan secara lebih terperinci tentang penjualan perusahaan selama periode yang akan datang, yang di dalamnya meliputi rencana tentang jenis (kualitas) barang yang akan dijual, jumlah (kuantitas) barang yang akan dijual, waktu penjualan serta tempat (daerah) penjualannya".

Tujuan utama dari anggaran penjualan adalah:

1. Untuk mengurangi ketidakpastian tentang pendapatan di masa yang akan datang.

2. Untuk memasukkan kebijaksanaan dan keputusan manajemen ke dalam proses perencanaan (misalnya dalam rencana pemasaran)

3. Untuk memberikan informasi penting bagi pembentukan elemen lain dari rencana laba yang menyeluruh.

4. Untuk memudahkan pengawasan manajemen atas kegiatan penjualan yang dilakukan.

Tujuan utama perusahaan adalah memperoleh keuntungan. Keuntungan akan diperoleh apabila perusahaan menjual barang/jasa dengan harga yang lebih dari harga pokoknya.Titik kritis penyusunan anggaran penjualan adalah membuat prakiraan penjualan, karena anggaran penjualan didasarkan pada prakiraan penjualan.

\subsubsection{Fungsi Dasar Anggaran Penjualan}

Anggaran penjualan terdiri atas dua fungsi dasar, yaitu:

1. Sebagai alat perencanaan

2. Sebagai alat pengawasan

\subsubsection{Kegunaan Anggaran Penjualan}

Anggaran penjualan yang disusun mempunyai kegunaan sebagai berikut:

1. Secara Umum

2. Secara Khusus

\subsubsection{Konsep Anggaran Penjualan}

Penyusunan konsep anggaran penjualan dapat dikatakan mencakup segala kegiatan di bidang penjualan. Komponen-komponen pokok konsep anggaran penjualan sebagai berikut:

1. Dasar-dasar penyusunan anggaran.

2. Menyusun anggaran penjualan..

Dalam melakukannya perlu dipertimbangkan beberapa faktor, seperti:

1. Karakteristik pasar yang dihadapi perusahaan.

2. Kemampuan Finansial

3. Keadaan Personalia.

4. Dimensi Waktu

\subsubsection{Faktor-faktor yang Mempengaruhi Penyusunan Anggaran Penjualan}

Suatu anggaran dapat berfungsi dengan baik bilamana taksiran-taksiran yang termuat di dalamnya cukup akurat, sehingga tidak jauh berbeda dengan realisasinya. Untuk bisa melakukan prakiraan secara lebih akurat, diperlukan berbagai data, informasi dan pengalaman, yang merupakan faktorfaktor yang harus dipertimbangkan di dalam menyusun anggaran penjualan, 
secara garis besar dapat dibedakan menjadi dua kelompok, ialah:

1. Faktor-faktor intern,yaitu data, informasi dan pengalaman yang terdapat di dalam perusahaan sendiri.

2. Faktor-faktor Ekstern, yaitu data, informasi dan pengalaman yang terdapat di luar perusahaan, tetapi di sana mempunyai pengaruh terhadap anggaran penjualan perusahaan.

\subsubsection{Langkah-langkah Penyusunan Anggaran Penjualan}

Dalam menyusun anggaran penjualan, langkah-langkah yang perlu dilakukan meliputi:

1. Penentuan dasar-dasar anggaran

2. Penyusunan rencana penjualan

a. Analisis ekonomi.

b. Melakukan analisis industri

c. Melakukan analisis prestasi penjualan yang lain

d. Analisis prestasi penjualan yang akan datang

\subsubsection{Pengertian Peramalan (Forecasting)}

Menurut Freddy Rangkuti (2008: 61), Peramalan (Forecasting) merupakan alat yang sangat penting dalam membuat estimasi berapa besarnya permintaan (demand). Menurut Hidayat Wiweko (hal.1), Forecast (perkiraan/ramalan) penjualan merupakan perkiraan penjualan pada suatu waktu yang akan datang dalam keadaan tertentu dan dibuat berdasarkan data-data yang pernah terjadi atau mungkin akan terjadi. Sedangkan menurut Gunawan Adisaputro dan Marwan Asri (2003:147), Peramalan penjualan adalah proyeksi teknis daripada permintaan langganan potensial untuk suatu waktu tertentu dengan berbagai asumsi.

Berdasarkan beberapa pengertian diatas dapat disimpulkan bahwa Peramalan penjualan adalah perkiraan penjualan pada waktu yang akan datang dalam keadaan tertentu dan dibuat berdasarkan data-data yang pernah terjadi pada waktu (tahun) sebelumnya.
Hasil dari suatu peramalan (forecast) lebih merupakan pernyataan atau penilaian yang kuantitatif terhadap permintaan konsumen potensial untuk jangka waktu tertentu. Meskipun demikian hasil perkiraan yang diperoleh mungkin saja tidak sama dengan rencana. Hal ini disebabkan karena:

a. Peramalan lebih merupakan pernyataan atau penelitian yang kuantitatif terhadap kondisi masa depan mengenai subjek tertentu, misalnya penjualan.

b. Peramalan penjualan merupakan proyeksi teknis dari permintaan konsumen potensial untuk jangka waktu tertentu dengan menyebutkan asumsi yang mendasarinya.

c. Peramalan selayaknya hanya dipandang sebagai bahan masukan untuk mengembangkan suatu rencana penjualan.

d. Manajemen dapat menerima atau menolak hasil suatu peramalan.

Pada umumnya hasil dari suatu peramalan penjualan akan dikonversikan menjadi rencana penjualan dengan memperhitungkan berbagai hal berikut:

1. Pendapat.

2. Strategi-strategiyang direncanakan.

3. Keterikatan/komitmen dengan sumber daya.

4. Ketetapan manajemen dalam usaha mencapai sasaran penjualan.

Dalam menjalankan usahanya, perusahaan dapat menganut salah satu dari dua pendekatan, yaitu:

1. Pendekatan Speculative, dimana perusahaan tidak memperhitungkan resiko yang diakibatkan oleh ketidakpastian faktor-faktor intern dan ekstern.

2. Pendekatan Calculated Risk, dimana perusahaan secara aktif melakukan estimasi terhadap resiko yang diakibatkan oleh ketidakpastian faktor-faktor ekstern dan intern.

3. Jenis-jenis Peramalan

Secara umum teknik peramalan yang diterapkan untuk memperoleh suatu 
peramalan penjualan dapat dikelompokkan menjadi:

a. Peramalan berdasarkan Pendapat (judgement)

Biasanya digunakan untuk menyusun peramalan penjualan maupun peramalan kondisi bisnis pada umumnya

Sumber pendapat-pendapat yang dipakai sebagai dasar melakukan peramalan adalah:

1) Pendapat Salesman

Para salesman diminta untuk mengukur apakah ada kemajuan atau kemunduran segala hal yang berhubungan dengan tingkat penjualan pada daerah mereka masing-masing. Kemudian mereka diminta untuk mengestimasi tentang tingkat penjualandi daerah masingmasing di waktu mendatang.

2) Pendapat Sales Manajer

Perkiraan yang dikemukakan oleh para salesman pelu diperbandingkan dengan perkiraan yang dibuat oleh kepala bagian penjualan. Seorang kepala bagian penjualan tentu mempunyai pertimbangan dan pandangan yang lebih luas meliputi seluruh daerah penjualan. Pada umumnya perkiraan kepala bagian penjualan dapat lebih obyektif karena mempertimbangkan banyak faktor.

3) Pendapat Para Ahli

Kadang-kadang perkiraan yang dibuat oleh salesman dan kepala bagian penjualan sangat bertentangan satu sama lain, sehingga perusahaan menganggap perlu untuk meminta pertimbangan kepada orang yang dianggap ahli. Mereka ini disebut konsultan.

4) Survey Konsumen

Apabila ketiga pendapat di atas masih dirasa kurang dapat dipertanggungjawabkan, maka diadakan penelitian langsung terhadap konsumen.

b. Peramalan berdasarkan Analisis Statistika

1) Apabila perhitungan berdasarkan data historis dari satu variabel saja, maka digunakan cara:

a) Metode Bebas (Free Hand's Method)
Metode ini memberikan kebebasan penuh untuk menggambarkan garis tren berupa garis lurus yang terletak di antara titik-titik data asli. Dapat dikatakan bahwa penerapan garis tren secara bebas merupakan suatu cara penerapan garis tren tanpa menggunakan rumus matematika.

b) Metode Semi Rata-rata (Semi Average's Method)

Dengan menggunakan metode ini data dibagi 2 bagian yang sama, masing-masing dicari nilai rataratanya. Dari 2 titik ini dapat digambarkan garis trennya.

c) Metode Rata-rata Bergerak (Moving average's Method)

Dengan metode ini, maka pengaruh gerak musim dan faktor-faktor lainnya dapat dihilangkan sehingga tren dapat dihitung.

d) Metode jumlah Kuadrat Terkecil (The Least Square's Method)

Jumlah kuadrat terkecil adalah jumlah kuadrat penyimpangan (deviasi) nilai data terhadap garis tren minimal atau terkecil. Apabila syarat ini dipenuhi, maka garis tren tersebut akan terletak di tengahtengah data asli.

2) Apabila perhitungan berdasarkan data historis dari satu variabel yang akan ditaksir dihubungkan dengan data historis lain yang mempunyai hubungan kuat terhadap perkembangan variabel yang akan ditaksir, maka digunakan cara:

a) Metode Korelasi

Korelasi tidak menunjukkan hubungan sebab akibat. Pada korelasi dijelaskan besarnya tingkat hubungan antara variabel yang satu dengan variabel yang lain.

b) Metode Regresi

Regresi menunjukkan hubungan antara variabel yang satu dengan variabel yang lain. Sifat hubungan ini juga dapat dijelaskan antara variabel yang satu sebagai penyebab sedangkan yang lain sebagai akibat, dalam bentuk variabel yang 
independen dan variabel yang dependen.

c) Peramalan berdasarkan Metode Khusus

1) Analisis Industri

Dalam analisis ini lebih ditekankan "market share" yang dimiliki perusahaan. Analisis ini menghubungkan potensi penjualan perusahaan dengan industri pada umumnya (volume, posisi dalam persaingan).Tahap dalam pemakaian analisis industri:

a) Membuat proyeksi penjualan industri untuk mengetahui prospek perkembangan penjualan industri pada tahun-tahun mendatang.

b) Menilai posisi perusahaan dalam persaingan

Market Share $=$

$\frac{\text { PermintaanPerusahaan }}{\text { PermintaanIndustri }} \times 100 \%$

c) Proyeksi posisi perusahaan pada masa mendatang atau perhitungan Expected Market Share

2) Analisis Product Line

Umumnya analisis product line digunakan pada perusahaan yang menghasilkan beberapa macam dan tidak mempunyai kesamaan sehingga dalam membuat ramalannya harus terpisah

3) Analisis Penggunaan Akhir

Analisis ini digunakan pada perusahaanperusahaan yang memproduksi barangbarang yang tidak langsung dapat dikonsumsi, melainkan masih memerlukan proses lebih lanjut untuk menjadi produk akhir.

Dapat disimpulkan bahwa ramalanpenjualan tidak hanya bisa diidentifikasi dari data kuantitatif atau statistik saja. Namun, juga dapat diidentifikasi berdasarkan Pendapat (judgement), analisis statistika dan metode khusus sesuai dengan jenis barang yang diproduksi. Jika satu metode dirasa kurang akurat dalam memperkirakan penjualan, misalnya dari pendapat salesman atau manajer penjualan maka digunakan metode analisis statistika guna mendukung data yang ada sehingga manajemen dapat meramal penjualan yang akan datang secara tepat dengan berbagai upaya-upaya untuk meningkatkan penjualan tersebut.

\subsubsection{Pengertian Metode Jumlah Kuadrat Terkecil (Least Square)}

Metode jumlah kuadrat terkecil atau metode least square (least square's method) adalah jumlah kuadrat penyimpangan (deviasi) nilai data terhadap garis tren minimum atau terkecil (Noegroho Boedijoewono, 2007:231).

Ciri dari metode ini, yaitu dalam menentukan parameter X. Setelah parameter $\mathrm{X}$ terbentuk dan dijumlah, jumlahnya harus 0 , walaupun dalam data historis berjumlah ganjil maupun data historis berjumlah genap.

1. Cara Menghitung

Dalam hal ini terhadap data dilakukan pembagian menjadi dua kelompok untuk data yang jumlahnya:

a) Genap, maka skor nilai-X-nya adalah.........-5,-3,-1,1,3,5

b) Ganjil, maka skor nilai $\mathrm{X}$-nya adalah.........-2,-1,0,1,2

2. Bentuk persamaan Tren

Tren penjualan adalah suatu garis naik atau turun yang menunjukkan tingkat penjualan.

Persamaan tren dapat mempunyai berbagai bentuk, yaitu:

a) Bentuk persamaan garis lurus dirumuskan:

$\mathrm{Y}^{\prime}=\mathrm{a}+\mathrm{bX}$

$\mathrm{Y}^{\prime}=$ Nilai variabel dependen

$\mathrm{X}=$ Nilai variabel independen dalam analisis tren (waktu)

$\mathrm{a}=$ Intercept $\mathrm{Y}$, yakni nilai $\mathrm{Y}$ apabila $\mathrm{X}=0$

$\mathrm{b}=$ Lereng garis tren

Persamaan ini menunjukkan garis lurus atau linier. Umumnya digunakan untuk data penjualan lebih dari 6 tahun, misal 10 tahun terakhir (data genap) dan 11 tahun terakhir (data ganjil).

b) Bentuk persamaan parabola, dirumuskan:

$Y^{\prime}=a+b X+c X^{2}$ 
Persamaan ini menunjukkan garis yang melengkung atau naik turun setengah lingkaran dan bersifat fleksibel atau fluktuasi. Umumnya digunakan untuk menghitung data 5 (lima) tahun terakhir.

c) Bentuk persamaan pangkat 3, dirumuskan:

$Y^{\prime}=a+b X+c X^{2}+d X^{3}$

Persamaan ini jarang digunakan karena dalam meramal cukup menggunakan dua persamaan saja. Sedangkan, persamaan ini membutuhkan 3 persamaan untuk menetukan nilai $\mathrm{d}$.

d) Bentuk persamaan eksponen, dirumuskan:

$\mathrm{Y}^{\prime}=\mathrm{ab} \mathrm{x}$

Persamaan ini juga jarang digunakan untuk meramal.

e) Bentuk Pearl Reed, dirumuskan:

$$
Y^{\prime}=\frac{1}{a+b c^{x}}
$$

Bentuk persamaan ini jarang digunakan untuk meramal karena sangat sulit mengidentifikasi komponen- komponennya.

Dari beberapa bentuk tren yang mudah digunakan dalam metode least square yaitu bisa menggunakan bentuk linear dan parabola. Namun, karena data yang digunakan adalah penjualan 5 (lima) tahun terakhir maka bentuk tren yang mudah digunakan adalah bentuk parabola yang menunjukkan naik turunnya penjualan. Bentuk linear digunakan untuk data yang lebih banyak, misal 10 tahun terakhir (genap) dan 11 tahun terakhir (ganjil) atau data lebih dari 6 (enam) tahun.

3) Perhitungan Persamaan Tren

I. $\sum \mathrm{Y}=\mathrm{Na}+\mathrm{b} \sum \mathrm{X}$

II. $\sum X Y=a \sum X+b \sum X^{2}$

Keterangan:

$\mathrm{Y}^{\prime}=$ Tren

$\mathrm{X}=$ Nilai independen variabel dalam analisis tren adalah waktu (tahun)

$\mathrm{Y}=$ Jumlah penjualan

$\mathrm{N}=$ Jumlah data

$\mathrm{a}, \mathrm{b}=$ Konstanta
Karena $\sum X=0$ (tahun di tengah $=0$ ), maka persamaan di atas menjadi:

$$
\begin{array}{ll}
\sum \mathrm{Y}=\mathrm{Na} & a=\frac{\Sigma Y}{\mathrm{n}} \\
\sum \mathrm{XY}=\mathrm{b} \sum \mathrm{X}^{2} & b=\frac{\Sigma X Y}{\Sigma X^{2}}
\end{array}
$$

4) Perhitungan tren berbentuk parabola

$$
\begin{aligned}
\text { I. } \sum \mathrm{Y} & =\mathrm{Na}+\mathrm{c} \sum \mathrm{X}^{2} \\
\text { II. } \sum \mathrm{X}^{2} \mathrm{Y} & =\mathrm{a} \sum \mathrm{X}^{2}+\mathrm{c} \sum \mathrm{X}^{4} \\
b & =\frac{\Sigma X Y}{\Sigma X^{2}}
\end{aligned}
$$

maka, $Y^{\prime}=\mathrm{a}+\mathrm{bX}+\mathrm{cX}^{2}$

(Noegroho Boedijoewono, 2007: 223-235)

Contoh1. Bentuk Persamaan Garis Lurus

a) Contoh Kasus Data Ganjil

Tabel 1. Volume Penjualan Buku "X" (dalam ribuan unit) Tahun 1995 - 2003

\begin{tabular}{|c|c|c|c|c|}
\hline Tahun & $\begin{array}{c}\text { Penjualan } \\
(\mathrm{Y})\end{array}$ & $\mathrm{X}$ & $\mathrm{XY}$ & $\mathrm{X}^{2}$ \\
\hline 1995 & 200 & -4 & -800 & 16 \\
\hline 1996 & 245 & -3 & -735 & 9 \\
\hline 1997 & 240 & -2 & -480 & 4 \\
\hline 1998 & 275 & -1 & -275 & 1 \\
\hline 1999 & 285 & 0 & 0 & 0 \\
\hline 2000 & 300 & 1 & 300 & 1 \\
\hline 2001 & 290 & 2 & 580 & 4 \\
\hline 2002 & 315 & 3 & 945 & 9 \\
\hline 2003 & 310 & 4 & 1240 & 16 \\
\hline Jumlah & 2460 & 0 & 775 & 60 \\
\hline
\end{tabular}

Untuk mencari nilai a dan $\mathrm{b}$ adalah sebagai berikut :

$\mathrm{a}=2.460 / 9=273,33$

$\mathrm{b}=775 / 60=12,92$

Persamaan garis liniernya adalah : $\mathrm{Y}=273,33+12,92 \mathrm{X}$

Dengan menggunakan persamaan tersebut, dapat diramalkan penjualanpada tahun 2010 adalah :

Untuk tahun 2010 nilai $\mathrm{X}$ adalah 11

$\mathrm{Y}=273,33+12,92(11)$

sehingga : $Y=273,33+142,12=415,45$

Artinya penjualan barang "X" pada tahun 2010 diperkirakan sebesar 415.450 unit. 
b) Contoh Kasus Data Genap

Tabel 2. Volume Penjualan Buku "X" (dalamribuan unit) Tahun 1995-2002

\begin{tabular}{|c|c|c|c|c|}
\hline Tahun & $\begin{array}{c}\text { Penjualan } \\
(\mathrm{Y})\end{array}$ & $\mathrm{X}$ & $\mathrm{XY}$ & $\mathrm{X}^{2}$ \\
\hline 1995 & 200 & -4 & -800 & 16 \\
\hline 1996 & 245 & -3 & -735 & 9 \\
\hline 1997 & 240 & -2 & -480 & 4 \\
\hline 1998 & 275 & -1 & -275 & 1 \\
\hline 1999 & 285 & 0 & 0 & 0 \\
\hline 2000 & 300 & 1 & 300 & 1 \\
\hline 2001 & 290 & 2 & 580 & 4 \\
\hline 2002 & 315 & 3 & 945 & 9 \\
\hline 2003 & 310 & 4 & 1240 & 16 \\
\hline Jumlah & 2460 & 0 & 775 & 60 \\
\hline
\end{tabular}

Untuk mencari nilai a dan $\mathrm{b}$ adalah sebagai berikut :

$$
\begin{aligned}
& \mathrm{a}=2.150 / 8=268,75 \\
& \mathrm{~b}=1.220 / 168=7,26
\end{aligned}
$$

Persamaan garis liniernya adalah : $\mathrm{Y}=268,75$ $+7,26 \mathrm{X}$

Dengan menggunakan persamaan tersebut, dapat diramalkan penjualan pada tahun 2008 adalah :

Untuk tahun 2008 nilai $\mathrm{X}$ adalah 19

$\mathrm{Y}=268,75+7,26(19)$

sehingga : $\mathrm{Y}=268,75+137,94=406,69$

Artinya penjualan barang " $X$ " pada tahun 2008 diperkirakan sebesar406,69 atau 406.690 unit.

\section{Bentuk Persamaan Parabola}

Tabel 3. Penjualan Komputer Tahun $2000-2004$

\begin{tabular}{|c|c|c|c|c|c|c|}
\hline Tahun & $\begin{array}{c}\text { Penjualan } \\
(\mathrm{Y})\end{array}$ & $\mathrm{X}$ & $\mathrm{X}^{2}$ & $\mathrm{X}^{4}$ & $\mathrm{XY}$ & $\mathrm{X}^{2} \mathrm{Y}$ \\
\hline 2000 & 13 & -2 & 4 & 16 & -26 & 52 \\
\hline 2001 & 24 & -1 & 1 & 1 & -24 & 24 \\
\hline 2002 & 39 & 0 & 0 & 0 & 0 & 0 \\
\hline 2003 & 65 & 1 & 1 & 1 & 65 & 65 \\
\hline 2004 & 106 & 2 & 4 & 16 & 212 & 424 \\
\hline & $\sum=247$ & 0 & $\sum=10$ & $\sum=34$ & $\sum=227$ & $\sum=565$ \\
\hline
\end{tabular}

Penyelesaian:

$$
\begin{aligned}
\text { I. } \sum \mathrm{Y} & =\mathrm{Na}+\mathrm{c} \sum \mathrm{X}^{2} \\
\text { II. } \sum \mathrm{X} 2 \mathrm{Y} & =\mathrm{a} \sum \mathrm{X}^{2}+\mathrm{c} \sum \mathrm{X}^{4} \\
\mathrm{~b} & =\sum \mathrm{XY} / \sum \mathrm{X}^{2} \\
\mathrm{~b} & =\frac{227}{10}
\end{aligned}
$$

$$
\begin{aligned}
& =22,7 \\
& 247=5 \mathrm{a}+10 \mathrm{c} \times 2 \\
& 565=10 \mathrm{a}+34 \mathrm{c} \times \mathrm{x} 1 \\
& 494=10 \mathrm{a}+20 \mathrm{c} \\
& 565=10 \mathrm{a}+34 \mathrm{c} \\
& -71=-14 \mathrm{c} \\
& \mathrm{c} \quad=5,07
\end{aligned}
$$

subtitusi ke persamaan I

$$
\begin{array}{ll}
247 & =5 \mathrm{a}+10 \mathrm{c} \\
247 & =5 \mathrm{a}+10(5,07) \\
247 & =5 \mathrm{a}+50,7 \\
5 \mathrm{a} & =196,3 \\
\mathrm{a} & =39,3 \\
\mathrm{Y}, & =\mathrm{a}+\mathrm{bX}+\mathrm{cX} \mathrm{X}^{2} \\
\mathrm{Y}, & =39,3+22,7 \mathrm{X}+5,07 \mathrm{X}^{2}
\end{array}
$$

Misal untuk ramalan penjualan tahun 2008 Nilai $X$ diganti 6 maka:

$\mathrm{Y}^{\prime}=39,3+22,7 \mathrm{X}+5,07 \mathrm{X}^{2}$

$Y^{\prime}=39,3+22,7(6)+5,07$ (6) 2

$\mathrm{Y}^{\prime}=39,3+136,2+182,52$

$=358,02$

Peramalan penjualan tahun $2008=358,02$ unit atau 358 unit.

\section{METODE PENELITIAN}

\subsection{Tempat dan Objek Penelitian}

Tempat penelitian : CV. Pangan Makmur Irja

Jl. Misool No. 22 Kel. Klabala Distrik Sorong Barat

Bergerak sebagai distributor perdagangan makanan dan minuman dari PT. Nestle Indonesia.

Objek penelitian : Produk Susu Kental Manis Carnation sebagai produk terlaris dari distributor tersebut di atas.

\subsection{Metode Pengumpulan Data :}

Metode pengumpulan data yang digunakan dalam penelitian ini adalah sebagai berikut :

a. Penelitian Kepustakaan, yaitu penelitian yang dilakukan dengan cara mempelajari dan mengumpulkan bahan-bahan kepustakaan, dan literatur-literatur yang ada kaitannya dengan penulisan skripsi ini. 
b. Penelitian Lapangan, yaitu penelitian yang dilakukan dengan teknik:

1. Observasi, yaitu teknik penelitian yang dilakukan dengan mengadakan pengamatan secara langsung dalam perusahaan untuk mendapatkan data-data yang berhubungan dengan pembahasan penelitian yang dilakukan.

2. Wawancara, yaitu teknik penelitian yang dilakukan dengan mengadakan wawancara atau tanya-jawab dengan pihak perusahaan yang ditunjuk atau pejabat berwenang yang ada hubungannya dengan data-data penjualan yang dibahas dalam penelitian ini.

\subsection{Jenis-jenis Data}

Dalam Penelitian ini penulis menggunakan data :

1. Data Kualitatuf yaitu, data yang diperoleh dari dalam perusahaan yang bukan dalam bentuk angka-angka tetapi dalam bentuk lisan maupun tertulis seperti gambaran umum perusahaan, struktur organisasi serta produk-produk yang dijual.

2. Data Kuantitatif, yaitu data atau informasi yang diperoleh dari perusahaan dalam bentuk angka-angka, yaitu data penjualan produk susu kental manis carnationselama 5 tahun dari tahun 2010-2014 dan data penjualan tahun 2015.

Sedangkan Sumber data sekunder yang digunakan penulis adalah:

1. Data Primer, yaitu data yang diperoleh dengan mengadakan pengamatan secara langsung pada perusahaan serta melakukan wawancara langsung dengan pihak yang berkaitan langsung dengan penelitian ini.

2. Data Sekunder, yaitu data yang dperoleh dengan jalan mengumpulkan dokumen-dokumen serta arsip-arsip perusahaan yang ada kaitannya dengan penulisan ini.

\subsection{Metode Analisis Data}

Metode analisis yang digunakan dalam penelitian ini adalah metode analisis deskriptif kuantitatif, yaitu suatu metode yang bersifat penjelasan dan keterangan dalam bentuk angka-angka dan tabel yang mendeskripsikan kembali apa yang diperoleh di lapangan dalam bentuk paparan statistik, sehingga penulis hanya menggambarkan seluruh peristiwa yang terjadi di lapangan dalam bentuk kuantitatif (angka) saja dengan cara menghitung garis tren penjualan yang terjadi untuk 5 tahun terakhir untuk mengambil kesimpulan. Adapun metode yang digunakan untuk menghitung yaitu dengan metode jumlah kuadrat terkecil (The Least Square's Method).

\section{PEMBAHASAN}

\subsection{Data Penjualan Produk Susu Kental Manis Carnation}

Data penjualan produk Susu Kental Manis Carnation pada CV. Pangan Makmur IRJA Sorong tahun 2010-2014 adalah sebagai berikut:

Tabel. 4.1 Data Penjualan

\begin{tabular}{|c|c|}
\hline Tahun & $\begin{array}{c}\text { Penjualan } \\
\text { (Karton) }\end{array}$ \\
\hline 2010 & 42.272 \\
\hline 2011 & 41.669 \\
\hline 2012 & 34.938 \\
\hline 2013 & 41.104 \\
\hline 2014 & 48.358 \\
\hline 2015 & 55.611 \\
\hline
\end{tabular}

Sumber data: CV. Pangan Makmur IRJA

Data penjualan tahun 2015 adalah data yang akan diramalkan dengan menggunakan metode jumlah kuadrat terkecil (The Least Square's Method).

\subsection{Data Anggaran Penjualan}

Tabel. 4.2 Data Anggaran Penjualan

\begin{tabular}{|c|c|c|c|}
\hline Tahun & $\begin{array}{c}\text { Unit yang } \\
\text { dianggark } \\
\text { an }\end{array}$ & $\begin{array}{c}\text { Harga / } \\
\text { Karton } \\
\text { (Rp.) }\end{array}$ & $\begin{array}{c}\text { Total Anggaran } \\
\text { Penjualan } \\
\text { (Rp.) }\end{array}$ \\
\hline 2010 & 45.000 & 306.000 & 13.770 .000 .000 \\
\hline 2011 & 45.000 & 312.000 & 14.040 .000 .000 \\
\hline
\end{tabular}




\begin{tabular}{|l|l|l|l|}
\hline 2012 & 42.000 & 333.000 & 13.986 .000 .000 \\
\hline 2013 & 42.000 & 357.000 & 14.994 .000 .000 \\
\hline 2014 & 42.000 & 384.000 & 16.128 .000 .000 \\
\hline
\end{tabular}

4.3 Data Hasil Penjualan Produk pada beberapa Daerah Pemasaran
1. Kota Sorong
$60 \%$
2. Kab. Sorong
$30 \%$
3. Kab. SorSel
$5 \%$
4. Kab. Raja Ampat
$5 \%$

\subsection{Data Realisasi Penjualan Produk}

Tabel. 4.3 Data Realisasi Penjualan

\begin{tabular}{|c|c|c|c|}
\hline Tahun & $\begin{array}{c}\text { Unit } \\
\text { yang } \\
\text { terjual }\end{array}$ & $\begin{array}{c}\text { Harga / } \\
\text { Karton } \\
\text { (Rp.) }\end{array}$ & $\begin{array}{c}\text { Total } \\
\text { Penjualan } \\
\text { (Rp.) }\end{array}$ \\
\hline 2010 & 40.272 & 306.000 & 12.323 .232 .000 \\
\hline 2011 & 41.669 & 312.000 & 13.000 .728 .000 \\
\hline 2012 & 34.938 & 333.000 & 11.634 .354 .000 \\
\hline 2013 & 41.104 & 357.000 & 14.674 .128 .000 \\
\hline 2014 & 48.358 & 384.000 & 18.569 .472 .000 \\
\hline
\end{tabular}

Sumber: Data diolah

\subsection{Perhitungan Penjualan Produk dengan Metode Jumlah Kuadrat Terkecil(The Least Square's Method)}

Tabel. 4.4 Perhitungan dengan Metode Jumlah Kuadrat Terkecil

(The Least Square's Method).

\begin{tabular}{|c|c|c|c|c|c|c|}
\hline Tahun & $\begin{array}{c}\text { Penjualan } \\
(\mathrm{Y})\end{array}$ & $\mathrm{X}$ & $\mathrm{X}^{2}$ & $\mathrm{X}^{4}$ & $\mathrm{XY}$ & $\mathrm{X}^{2} \mathrm{Y}$ \\
\hline 2010 & 40.272 & -2 & 4 & 16 & -80.544 & 161.088 \\
\hline 2011 & 41.669 & -1 & 1 & 1 & -41.669 & 41.669 \\
\hline 2012 & 34.938 & 0 & 0 & 0 & 0 & 0 \\
\hline 2013 & 41.104 & 1 & 1 & 1 & 41.104 & 41.104 \\
\hline 2014 & 48.358 & 2 & 4 & 16 & 96.716 & 193.432 \\
\hline & $\sum=206.341$ & 0 & $\sum=10$ & $\sum=34$ & $\sum=15.607$ & $\sum=437.293$ \\
\hline
\end{tabular}

Sumber : Data diolah

Perhitungan tren

Penyelesaian dengan rumus berikut:

$$
\begin{array}{ll}
\text { I. } \sum \mathrm{Y} & =\mathrm{Na}+\mathrm{c} \sum \mathrm{X}^{2} \\
\text { II. } \sum \mathrm{X} 2 \mathrm{Y} & =\mathrm{a} \sum \mathrm{X}^{2}+\mathrm{c} \sum \mathrm{X}^{4} \\
\mathrm{~b} & =\sum \mathrm{XY} / \sum \mathrm{X}^{2} \\
\mathrm{~b} & =\frac{15.607}{10} \\
& =1.561
\end{array}
$$

$$
\begin{aligned}
& 206.341=5 \mathrm{a}+10 \mathrm{c} \times\left.\right|^{2} \\
& 437.293=10 \mathrm{a}+34 \mathrm{cx} \\
& 412.682=10 \mathrm{a}+20 \mathrm{c}
\end{aligned}
$$

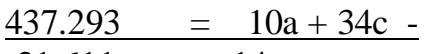

$$
\begin{aligned}
& -21.611=-14 \mathrm{c} \\
& =1.543,642
\end{aligned}
$$

subtitusi ke persamaan I

$$
\begin{aligned}
206.341 & =5 \mathrm{a}+10 \mathrm{c} \\
206.341 & =5 \mathrm{a}+10(1.543,642) \\
206.341 & =5 \mathrm{a}+15.436,42 \\
5 \mathrm{a} & =206.341-15.436,42 \\
5 \mathrm{a} & =190.904,58 \\
\mathrm{a} & =190.904,58 / 5 \\
\mathrm{a} & =38.180,916
\end{aligned}
$$

jadi trennya adalah $\mathrm{Y}^{\prime}=\mathrm{a}+\mathrm{bx}+\mathrm{cx}^{2}$

$\mathrm{Y}^{\prime}=38.180,916+4.130,4 \mathrm{X}+1.543,642 \mathrm{X}^{2}$

Dari hasil perhitungan tren menggunakan metode jumlah kuadrat terkecil (The Least Square's Method) maka dapat dihitung perkiraan atau peramalan penjualan produk Susu Kental Manis Carnation pada CV. Pangan Makmur IRJA Sorong yaitu: Jarak antara tahun 2013 sampai dengan tahun $2015=$ 3 tahun, jadi nilai $\mathrm{X}$ diganti dengan 3 .

Perhitungannya adalah:

$\mathrm{Y}^{\prime}=\mathrm{a}+\mathrm{bX}+\mathrm{cX}^{2}$

$\mathrm{Y}^{\prime}=38.180,916+1.561 \mathrm{X}+1.543,642 \mathrm{X}^{2}$

$Y^{\prime}=38.180,916+1.561(3)+1.543,642(3)^{2}$

$Y^{\prime}=38.180,916+4.683+13.892,778$

$\mathrm{Y}^{\prime}=56.756,694$

\subsection{Data Perhitungan Trend Penjualan}

Tabel. 4.5. Perhitungan Trend Penjualan

\begin{tabular}{|c|c|c|c|c|}
\hline Tahun & Penjualan & $\mathrm{X}$ & $\mathrm{XY}$ & $\mathrm{X}^{2}$ \\
\hline 2010 & 40.272 & -2 & -80.544 & -4 \\
\hline 2011 & 41.669 & -1 & -41.669 & -1 \\
\hline 2012 & 34.938 & 0 & 0 & 0 \\
\hline 2013 & 41.104 & 1 & 41.104 & 1 \\
\hline 2014 & 48.358 & 2 & 96.716 & 4 \\
\hline & $\sum=206.341$ & 0 & $\sum=15.607$ & $\sum=10$ \\
\hline
\end{tabular}

$$
\begin{aligned}
& a=\frac{206.341}{5} \\
& =41.267=1.561 \\
& Y=41.268+1.561 X \\
& \mathrm{Y} 2010=40.272+1.561(-2)=37.150 \\
& \text { Y } 2011=41.669+1.561(-1)=40.108 \\
& \text { Y } 2012=34.938+1.561(0)=36.499
\end{aligned}
$$




$$
\begin{aligned}
& \text { Y } 2013=41.104+1.561(1)=42.665 \\
& \text { Y } 2014=48.358+1.561(2)=51.480
\end{aligned}
$$

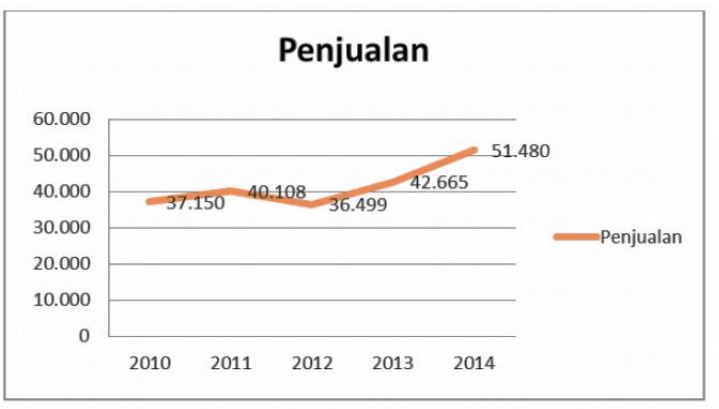

Gambar 4.6. Grafik Trend Penjualan dengan Metode Jumlah Kuadrat Terkecil

(The Least Square's Method)

\section{KESIMPULAN DAN SARAN}

\subsection{Kesimpulan}

Berdasarkan hasil pembahasan mengenai peramalan penjualan produk susu kental manis Carnation pada CV. Pangan Makmur IRJA tahun 2015 adalah :

1. Hasil peramalan yang diberikan oleh metode least square dalam data penjualan menunjukkan adanya kenaikan jumlah penjualan sebesar 56.756 karton lebih besar dari perhitungan yang digunakan oleh perusahaan berdasarkan judgement salesman sebesar 55.611 karton, ini menunjukkan bahwa metode least square merupakan metode yang lebih tepat digunakan karena metode ini sangat teliti dalam menghitung data berkala, dapat mencegah adanya kesalahan dalam pengsisian data dan membuat data akan semakin akurat serta dapat mempersingkat waktu untuk menghitung trend penjualan yang sudah ditentukan.

2. Hasil analisa korelasi menunjukkan adanya hubungan saling mempengaruhi dan sangat kuat antara hasil penjualan susu kental manis carnation berdasarkan perhitungan perusahaan dengan perhitungan penjualan berdasarkan metode least square karena korelasi tersebut mendekati +1 atau $92 . \%$

\subsection{Saran}

Berdasarkan hasil kesimpulan penelitian ini maka penulis memberikan saran sebagai berikut:

1. Pada perhitungan dengan metode least square sangat diperlukan ketelitian dan kecermatan agar tidak terjadi kesalahan dalam perhitungan.

2. Manajemen perlu menggunakan metode kuadrat terkecil dalam membuat peramalan (forecast) penjualan karena metode ini sangat teliti dalam mendeskripisikan angkaangka dalam perhitungan dan dapat mencegah adanya kesalahan dalam pengisian data, membuat data semakin akurat serta dapat mempersingkat waktu untuk menghitung trend penjualan yang sudah ditentukan.

3. Melakukan kerjasama yang baik antara tim penjualan dan manajemen terkait agar pencapaian target terpenuhi setiap bulannya.

4. Manajemen tetap berupaya untuk menjaga citra perusahaan dan produk dengan cara melakukan kegiatan yang menarik minat pelanggan dalam menjaga kepercayaan serta kepuasan pelanggan.

\section{DAFTAR PUSTAKA}

Rangkutti Freddy, (2008). Business Plan. Jakarta: Gramedia Pustaka Utama.

Adisaputro Gunawan dan Asri Marwan. (2003) Anggaran Perusahaan. Yogyakarta: BPFE.

Wiweko "Forecasting Penjualan"Modul tidak diterbitkan. Universitas Mercu Buana.

Boedijoewono Noegroho. (2007) Pengantar Statistika Ekonomi dan Bisnis. Yogyakarta: STIM YKPN.

Nurmatian. (2007) "Anggaran Penjualan". Modul tidak diterbitkan. Fakultas Ekonomi Universitas Mercu Buana Jakarta.

Christina, Ellen, M. Fuad, Sugiarto \& Sukarna Edy. 2001. Anggaran Perusahaansuatu pendekatan praktis. Edisi Pertama PT. Gramedia Pustaka Utama Jakarta. 
Gitosudarmo Indriyo. Anggaran Perusahaan, Teori dan Soal Jawab. Edisi

Pertama. Fakultas Ekonomi UGM Yogyakarta. 